JPPIPA 7(2) (2021)

\title{
Development of e-Student Worksheets Based on Multiple Representations of Factors Affecting Reaction Rates
}

\author{
Farah Meutia $^{1 *}$, Nurdin ${ }^{1}$, Sri Winarni ${ }^{1}$ \\ ${ }^{1}$ Study Program of Science Education, Postgraduate Program, University of Syiah Kuala, Banda Aceh, Indonesia
}

DOI: $\underline{10.29303 / \text { jppipa.v7i2.533 }}$

\section{Article Info}

Received: December 20th, 2020

Revised: February 10 $10^{\text {th }}, 2021$

Accepted: February 10th, 2021

\begin{abstract}
The research had been carried out to develop the e-student worksheet (e-SW) based on multiple representational learning models on the material factors which affect the rate of reaction to determine its effectiveness in understanding the concepts and activities of students, as well as the teacher's and the student's responses towards e-worksheet application. The research method and development (R\&D) of the Analysis, Design, Development, Implementation, and Evaluation (ADDIE) model were used for the development of e-SW. The research samples used were the students of class XI MIPA 1, and the chemistry teachers of class XI of senior high school 3 Banda Aceh, then the determination of the sample for implementation was carried out using random sampling techniques. Based on the results of the study, it can be concluded that an e-worksheet based on the developed multiple representation learning models on the factors which affect the reaction rate fulfilled the very feasible criteria with the acquisition of validity and reliability of 0.85 and 85 . Complete understanding of the concepts and activities of students using eworksheet was splendid, namely 84.8 and $85 \%$. The response of students and teachers to the development of e-worksheet based on the multiple representation learning models was also splendid.
\end{abstract}

Keywords: e-student worksheet; multiple representations; reaction rate

Citation: Meutia, F., Nurdin, N., \& Winarni, S. (2021). Development of e-Student Worksheets Based on Multiple Representations of Factors Affecting Reaction Rates. Jurnal Penelitian Pendidikan IPA, 7(2), 129-136. doi:https://doi.org/10.29303/ippipa.v7i2.533

\section{Introduction}

During the Covid-19 pandemic, the government decided to implement learning from the home policy with an online (brave) or online system. Therefore, teachers are required to be able to create a learning process boldly and creative and innovative teaching materials so that students can absorb learning knowledge well, one of which is the presentation of eSW using electronic media or what is known as student electronic sheets (e-SW) (Asma, et al., 2020). e-SW is a learning tool designed electronically, contains systematic and interesting material to achieve the expected competencies, and can access it anywhere and anytime (Supriadi, 2015).
Chemistry learning either directly or at discussing abstract topics that require visualization to improve students' understanding of concept by linking the three levels of representation, namely macroscopic, submicroscopic, and symbolic (Susilaningsih, et al., 2019). One of the materials in chemistry that involve the relationship between the three levels are reaction rates (Wiyarsi, et al., 2019). In fact, there are still many teachers who do not link the three levels, namely macroscopic, submicroscopic, and symbolic in learning (Nurpratami, et al., 2015; Fitri, 2016).

In chemistry learning, teachers emphasize the macroscopic level rather than the submicroscopic and symbolic level, so that students are unable to imagine how the processes and structures of a substance are. 
Therefore, various forms of representation are needed that can visualize the material and it is hoped that students can observe the symptoms that occur, analyze, and draw conclusions so that students will get a concept that can be understood and not only memorized in nature ( $\mathrm{Li}$ and Arshad, 2014; Alighiri et al., 2018). Efforts to solve chemical problems will be easier if learning chemistry is done by practicing using multiple representational abilities (Sari \& Seprianto, 2018).

Learning that involves macro-submicro-symbolic phenomena can improve the mental models of students and the effectiveness of learning. Multiple representation interconnection learning is effective in correcting students' misconceptions on stoichiometric material (Sunyono, et al., 2015; Nilawati, et al., 2016). The multiple representation-based learning models are more effective in improving the conceptual understanding of low and medium ability students (Sunyono \& Meristin, 2018).

The results of the needs analysis that had been carried out at senior high school 3 Banda Aceh obtained several problems that occurred in the learning process, namely the teacher had not done the learning that linked the three levels of representation, especially on the material factors that affected the rate of reaction, where the teacher focused more on learning on formula writing training. molecules, training in chemical calculations, and memorizing reactions, and does not focus on how to process and describe the events of the reaction rate itself. Then, the teaching materials in schools, especially in the material reaction rate are still limited and the available student worksheets are only practicum worksheets, and the characteristics of students' understanding in the chemistry learning process vary, where not all students quickly understand the chemistry material being taught.

Based on these problems, we need a learning model that can accommodate the three levels of representation and that is able to access learning needs with various backgrounds of students' abilities, namely a multiple representation learning models supported by teaching materials that have been developed in accordance with online learning conditions, namely multiple-based e-SW. representation. Student worksheets based on multiple representations can be used to improve students' creative thinking skills (Mutia \& Prasetyo, 2018). Student worksheet based on multiple representations is effective in increasing the mastery of concepts in chemical materials (Yuliana, et al., 2018).

\section{Method}

Research data collection was carried out at Senior high school 3 Banda Aceh in the odd semester of the 2020/2021 school year from September 1 to November 25, 2020. Development of e-SW uses the ADDIE model research and development (R\&D) method with the stages of Analysis, Design, Development, Implementation, and Evaluation. The selection of the ADDIE development stage is due to the ADDIE learning process which has been commonly used both traditionally by teaching material developers (Cahyadi, 2019).

ADDIE procedures, namely: (1) Analysis, which consists of performance analysis, student character analysis, and learning material needs, and material analysis; (2) Design, the design process of e-SW design which will be designed in such a way based on a multiple representation learning models in accordance with the criteria of a good worksheet; (3) Development, at this stage the e-SW design has been created and validated and the design has been revised; (4) Implementation, the results of the worksheet products that have been obtained and meet the requirements and are valid are then given to students so that learning can be done online through Microsoft Teams; (5) Evaluation, at this stage several aspects will be assessed, namely the results of student activities, student understanding of concepts, student responses and teachers of Senior high school 3 Banda Aceh.

The instruments used were needs analysis sheets, student characteristics analysis sheets, questionnaire sheets, student activity sheets that had been validated by a team of experts in their fields. The population of this e-SW development research was all chemistry teachers and students of class XI senior high school 3 Banda Aceh. The implementation population (trial) was all first semester students of class XI IPA at Senior high school 3 Banda Aceh in the 2020/2021 school year. The sample for the collection of teacher response data was all 5 chemistry teachers in class XI and the determination of the implementation sample was carried out by purposive sampling techniques and use the implementation design of one-shot case study. The students selected were 33 students of class XI MIPA 1 .

The results of the data obtained during the next study were analyzed for the data, tested for validity using expert agreement stated by Gregory (2007), by making a contingency table for two experts which can be seen in Table 1.

Table 1. Contingency Table

\begin{tabular}{llll}
\hline & & Rater 1 & \\
\cline { 3 - 4 } & & Weak & Strong \\
\hline \multirow{2}{*}{ Rater 2 } & Weak & A & B \\
& Strong & C & D \\
\hline
\end{tabular}




$$
\text { Validity Coefficient }=\frac{\mathrm{D}}{\mathrm{A}+\mathrm{B}+\mathrm{C}+\mathrm{D}}
$$

The scoring of the validity assessment of e-SW and research instruments can be seen in Table 2 .

Table 2. Interpretation of the Validity Assessment

\begin{tabular}{lll}
\hline No & Indeks Gregory & Category \\
\hline 1 & $<0,4$ & Low Validity \\
2 & $0,4-0,8$ & Moderate Validity \\
3 & $>0,8$ & High Validity \\
\hline & & (Source: Retnawati, 2016)
\end{tabular}

Then, the $e-S W$ reliability was tested and the research instrument used Inter-Rater Reliability (IRA) by utilizing two raters. How to estimate reliability can be calculated with the following formula (Retnawati, 2016).

$$
\text { IRA }=\frac{\text { The mumber of caces that are divcemis the same by bothraters }}{\text { Number of Caves }} \times 100
$$

The validation result is said to be reliable if the percentage agreement is $>75 \%$ (Ibrahim, et al., 2020).

\section{Result and Discussion}

\section{Development of e-SW based on multiple representations}

Development research using the ADDIE stage which aims to produce a product, namely e-SW which is designed based on multiple representation learning models. The description of each ADDIE stage carried out by researchers in developing multiple representation-based e-SW is as follows:

\section{Analysis Stage}

This stage is the first step in developing a multiple representation-based e-SW. The purpose of this stage is to find out what things are needed in order to get a proper e-SW.

a. Performance Analysis

This stage describes common problems faced in the chemistry learning process that has been carried out by several previous researchers. The textbooks used are only in the form of a composition of definitions and material summaries that do not pay attention to chemical concepts at 3 levels of representation, namely macroscopic, microscopic, and symbolic (Pahriah \& Hendrawani, 2018). Sundami \& Azhar (2019) report that the lack of application of 3 levels of representation in learning is one of the factors that cause chemical material to be difficult for students to understand because in chemistry there are so many abstract concepts. The results of the Needs Analysis through a questionnaire on the chemistry teacher senior high school 3 Banda Aceh, are as follows: (1) The teacher rarely links the three levels of multiple representations in the learning process; (2) The available worksheet is only in the form of practicum worksheet; (3) The characteristics of students vary, namely that some are quick to accept material and some are slow to accept or understand the material.

b. Student Analysis

At this stage, an analysis of student characteristics is carried out in terms of several aspects, namely learning interest, learning motivation, learning independence. The results of the analysis of student characteristics will be taken into consideration in developing e-SW based on multiple representation learning models. This stage is carried out by distributing questionnaires to class XI MIPA students. The results of data acquisition for student characteristics can be seen in Figure 1.

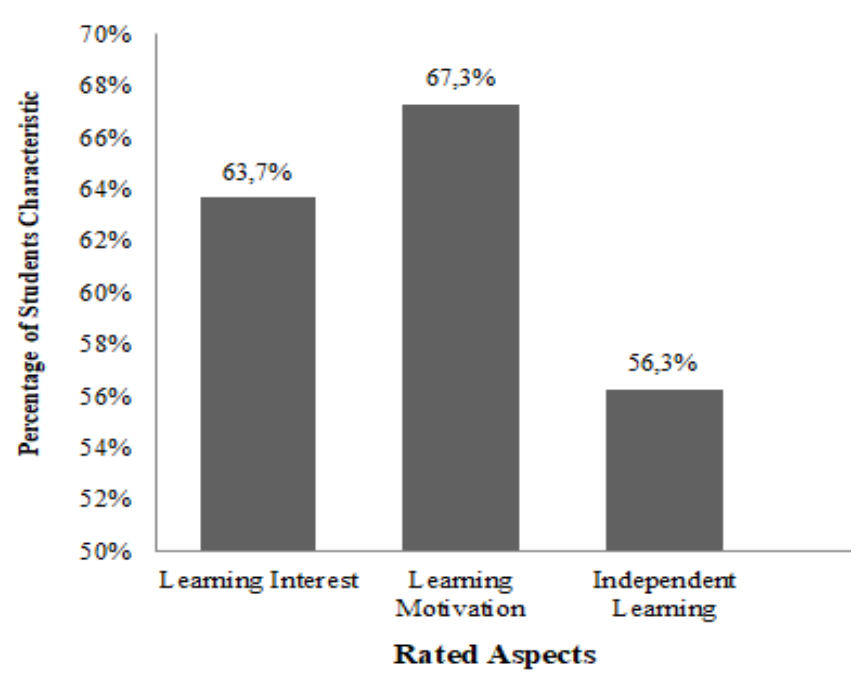

Figure 1. Analysis of Student Characteristics

The results of the analysis in Figure 1 show that the indicators of learning interest, student learning motivation, and learning independence are 63.7; 67.3; and $56.3 \%$. Independence in learning is the lowest student characteristic. According to Putri and Festiyed (2019), they report that independent learning is needed in the current advancement of technology and information, if students fail to build independence in learning it will have an impact on student success. In addition to interest, motivation, and learning independence, student learning styles are also analyzed which aims to see which learning styles are most suitable for students which consist of 3 aspects, namely audio, visual and kinesthetic learning styles, so that the e-SW designed will be adjusted to the style student learning. The results of the analysis of student learning styles can be seen in Figure 2. 


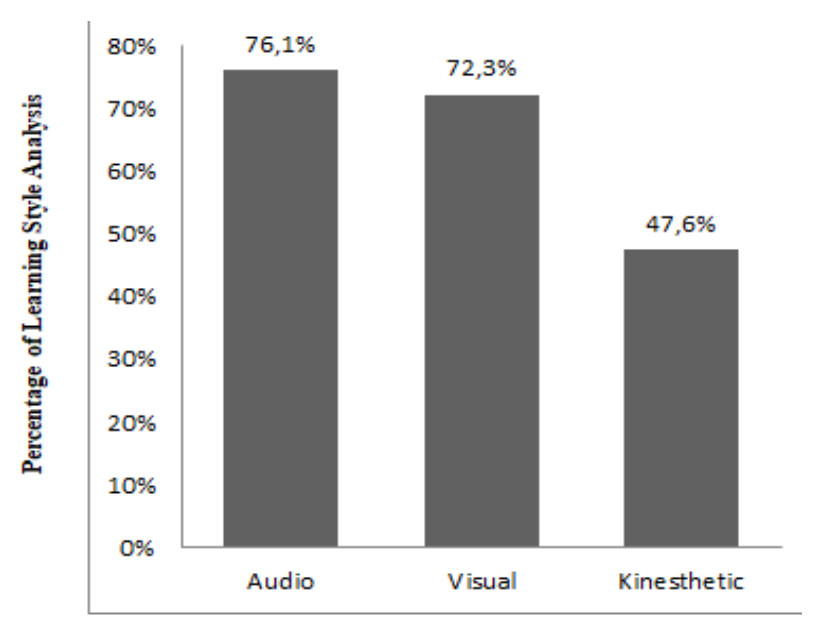

Rated Aspect

Figure 2. Results of Analysis of Student Learning Styles

The results of the analysis can be seen that the audio and visual learning styles obtain success proportions of 76.1 and $72.3 \%$ respectively.

Based on the results of the student analysis, the multiple representation-based e-SW learning models are very suitable to be developed and implemented to students because: (1) worksheet is designed digitally, so that students can access it wherever and whenever as well. is expected to increase the independence of students in studying chemicals, especially the factors that affect the rate of reaction; (2) E-SW based on the multiple representation learning models, there is an exploration-imagination stage, where at this stage it requires students to conduct group discussions and present their findings so that they can adjust students' learning styles in audio; (3) e-SW based on multiple representational learning models also presents some content such as images, learning videos, learning animations that link learning levels macroscopically, sub-microscopically, and symbolically, so that it can visually adjust student learning styles. Learning with visual representations would result in higher learning performance and lower cognitive load (Hsin, et al., 2015).

c. Material Analysis

In this stage, the analysis is carried out using the literature study method which aims to identify the main parts of the material to be taught and arranged systematically. The results of the material analysis are the factors that influence the rate of reaction, namely the concept of reaction rate, collision theory, and activation energy, as well as factors that affect the rate of reaction (concentration, temperature, surface area, and catalyst).

\section{Design Stage}

At this stage, what is done is designing the e-SW and compiling instruments that support the development process. The preparation of e-SW takes into account the important elements in the e-SW development process, namely titles, study instructions, basic competencies or subject matter, supporting information, tasks/work steps, and assessments (Prastowo, 2015). The e-SW draft that has been designed can be seen in Figure 3.

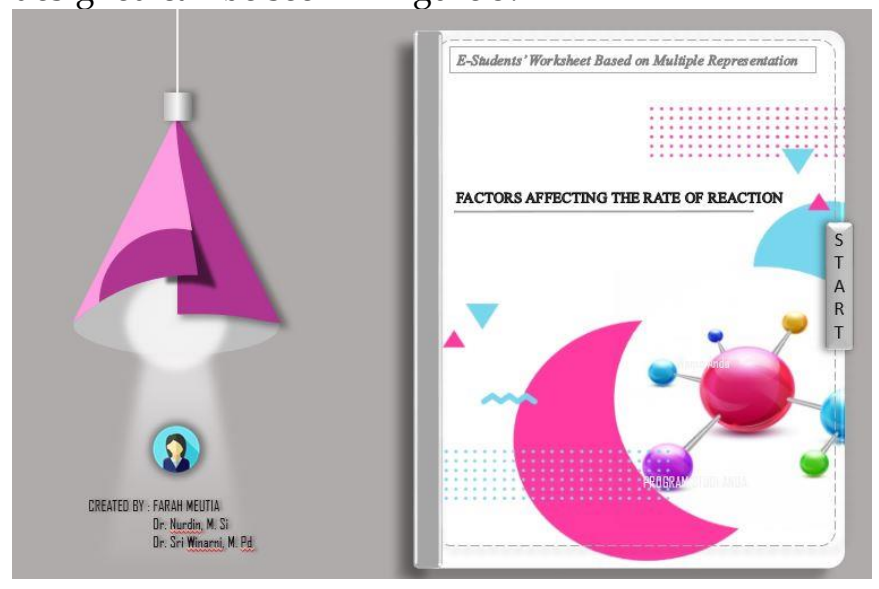

\section{Exploration-Imagination Stage}

3. The diagram below describes the initial stage of the reaction

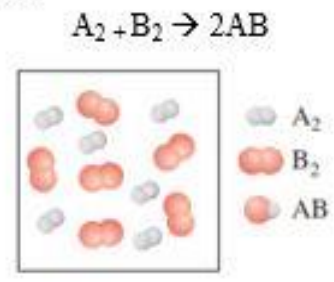

The reaction occurs at two temperatures shown as below:

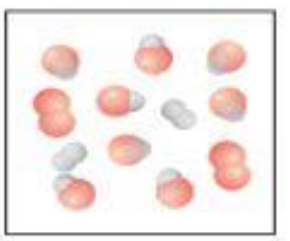

(a)

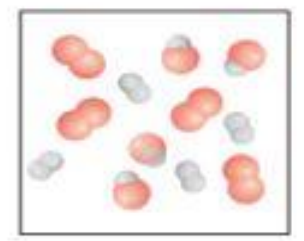

(b)
Which figures shows the reaction product at a higher temperature?

Figure 3. e-SW Preliminary Design

$e-S W$ is designed using i-Spring Suite 8. I-Spring is learning software that is integrated directly with Microsoft PowerPoint. iSpring Suite 8 is a software that can convert presentation files (ppt format) to flash (SWF format) (Himmah \& Martini, 2017). The design results are then submitted to the expert to be asked for suggestions so that the e-SW that has been designed is better. 


\section{Development Stage}

At this stage, the validation process for the eSW has been developed. The E-SW was validated by 3 validators, namely 2 expert lecturers and 1 chemistry teacher. The assessment of the quality of e-SW is based in terms of material aspects, learning model components, presentation, readability, and attractiveness of the design. During the validation process, there are parts that need to be revised, suggestions and improvements can be seen in Table 3 .

Table 3. Validator Suggestions Against $e-S W$

\begin{tabular}{ll}
\hline Validator & \multicolumn{1}{c}{ Suggestion } \\
\hline 1 & - Need to increase image resolution \\
- Increase the font size of some image captions \\
that are still relatively small \\
- At the orientation stage, chemical phenomena \\
that occur in everyday life and pictures \\
should also be shown \\
- Pay attention to the stages of the learning \\
model multiple representations are clearly \\
described on e-SW \\
- Make sure that each question in drawing \\
conclusions on the picture/illustration is \\
given an initial introduction so that students \\
are not confused so that the answer will be \\
more directed towards the desired answer \\
- We recommend that you add a bibliography \\
- The description in Figure 3 should be clarified \\
- Added hint / function symbols in e-SW \\
- In learning objectives, it is better if each item \\
is associated with a macroscopic, \\
submicroscopic, and symbolic level
\end{tabular}

The results of the revision of e-SW based on suggestions from the validator can be seen more clearly in Figure 4.

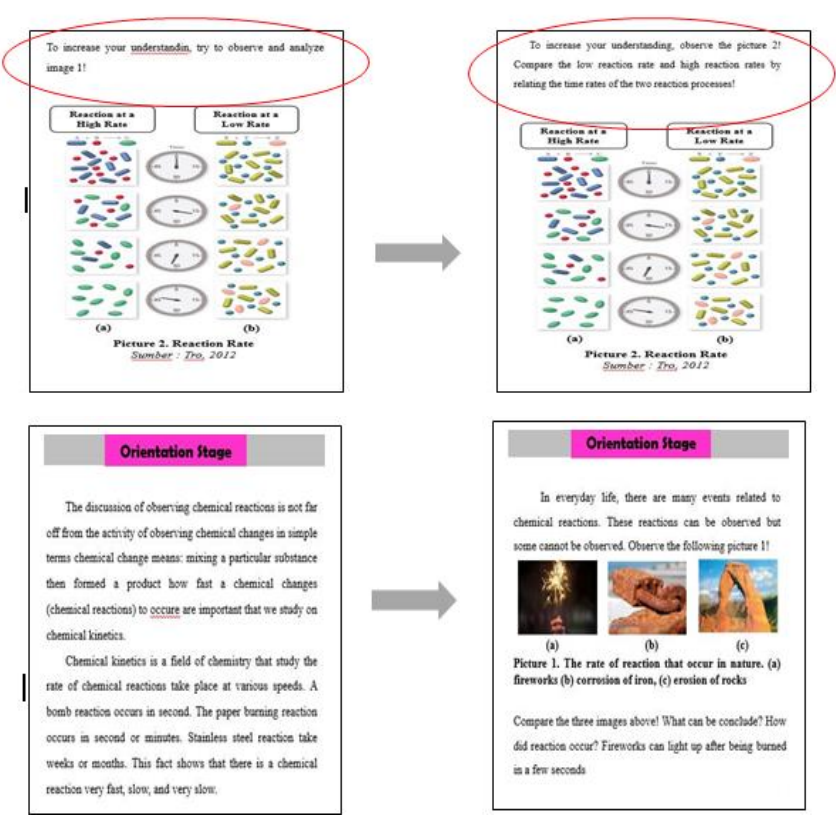

Figure 4. Design Revision Results

The e-SW assessment by the validator is based on 5 aspects, namely material, components of the multiple representation learning models, presentation, readability, and attractiveness of the design. These five aspects are used as benchmarks to state whether or not the e-SW has been developed. Apart from the e-SW assessment, the research instrument was also validated. The results of the analysis of the validity and reliability of e-SW and the research instruments can be seen in Table 4.

Table 4. Results of $e$-SW Validation and Research Instruments

\begin{tabular}{llllll}
\hline No & Rated aspect & Index & Category & $\begin{array}{c}\text { Percentage } \\
\text { Agreement }\end{array}$ & Category \\
\hline 1. & e-SW & 0.85 & High Validity & 85 & Reliable \\
2. & E-SW Assessment Instrument & 1 & High Validity & 80 & Reliable \\
3. & Questions & 1 & High Validity & 90 & Reliable \\
4. & Activity Assessment Instruments & 1 & High Validity & 100 & Reliable \\
5. & Student Response Questionnaire Instrument & 1 & High Validity & 88 & Reliable \\
6. & Teacher's Response Questionnaire Instrument & 1 & High Validity & 100 & Reliable \\
7. & Student Characteristics Assessment Instruments & 1 & High Validity & 84.6 & Reliable \\
\hline
\end{tabular}

\section{Implementation (Test) Stage}

At this stage, after the developed e-SW is declared valid and reliable, the e-SW is tested on students. The implementation of this research was carried out in a limited manner which was piloted in the senior high school 3 Banda Aceh. This implementation was carried out in November 2020 for 33 MIPA 1 class XI students.

The implementation process is carried out online using the Microsoft Teams application. Microsoft
Teams is one of the online learning media designed in Microsoft 365 that brings together conversations, content, assignments, and applications in one place that allows teachers to create a dynamic learning environment, and can also offer distance learning experiences that can be socially connected such as learning. in-class (Situmorang, 2020). The trial was carried out to see how the activities and conceptual understanding of students and the responses of 
students and teachers to the e-SW trial were based on the multiple representation learning models.

\section{Evaluation Stage}

At this stage, an evaluation of the results of the eSW feasibility assessment is carried out, student responses, teacher responses, observations of student activities, and student understanding of concepts so that it can be concluded whether the e-SW based on the multiple representation learning models that have been developed is feasible or not for use in chemistry studies with the factors that affect the rate of reaction.

\section{a. Students' Concept Understanding}

Concept understanding is seen based on the results of students' learning completeness which is measured based on the minimum completeness criteria value at senior high school 3 Banda Aceh, namely 76 . The results of the student understanding test can be seen in Table 5.

Table 5. Results of Students' Concept Understanding

\begin{tabular}{llll}
\hline Value & Completeness & $\begin{array}{l}\text { Number of } \\
\text { Students }\end{array}$ & Percentage \\
\hline$\geq 76$ & Completed & 28 & $84.8 \%$ \\
$<76$ & Not Completed & 5 & $15.2 \%$ \\
Amount & & 33 & $100 \%$ \\
\hline
\end{tabular}

Based on Table 3, it can be seen that 28 students have achieved mastery learning with a percentage of $84.8 \%$, while students who have not achieved completeness in learning are 5 people with a percentage of $15.2 \%$. A class is said to have completed learning if in the class there are $\geq 75 \%$ of students who have completed learning (Sumaryati, et al., 2018). This means that students can understand the material factors that affect the rate of reaction macroscopically, sub, and symbolically. This shows that their understanding is high order thinking because E-SW is full of intellectual stimuli. so that e-SW based on multiple representational learning models applied to students is effective in understanding students' concepts. The multiple learning models of representation are effective on students' mastery of concepts (Lestari, et al., 2020; Kusumaningsih, et al., 2018).

\section{b. Student Activity}

Observations of student activities during the multiple representation-based e-SW trials using the observation assessment sheet instrument of student activities. This observation sheet was filled in by 2 observers. The observer was a senior high school 3 Banda Aceh teacher. Observers/observers observe the activities of students during online learning.

Recapitulation of student activity observations in the activity analysis obtained a percentage of $85 \%$, it can be concluded that the activity after using e-SW based on the multiple representation learning models is very good, such as the research results of Sutamiati, et al. (2015) reported that the activities of students in learning using e-SW based on multiple representations continued to increase from the first to the fourth meeting). Likewise, the research results (Putrizal, 2015) reported an increase in student activity after the use of multiple representation-based worksheets.

c. Responses of Students and Teachers on the Development of e-SW Based on Multiple Representation Learning Models

Students who filled out the questionnaire responses to e-SW were 5 students who had conducted the e-SW trial, while the teachers who filled out the response questionnaire were 5 chemistry teachers at senior high school 3 Banda Aceh.

Students gave a very good response to the developed e-SW, namely the acquisition of an average score of $81.39 \%$. In addition to the positive responses given by students, the teacher also gave a very good response to the e-SW that was developed, namely the acquisition of an average score of $93.5 \%$ with very good criteria. Student responses to multiple representationbased teaching materials show a positive response (Helsy, et al., 2017). The multiple representation-based worksheets that were developed received good responses from teachers and students (Noor, et al., 2019).

\section{Conclusion}

Based on the results of the study, it can be concluded that the e-SW based on the multiple representation learning models developed on the factors that affect the reaction rate fulfills the very feasible criteria and can be used. The completeness of understanding the concept of students using e-SW is very good, namely $84.85 \%$. The activity of students using e-SW was very good, namely $85 \%$. The response of students and teachers to e-SW based on the multiple representation learning models that were developed was very good.

\section{References}

Alighiri, D., Drastisianti, A., \& Susilaningsih, E. (2018). Pemahaman Konsep Siswa Materi arutan Penyangga dalam Pembalajaran Multipele Representasi. Jurnal Inovasi Pendidikan Kimia. 12(2):2192-2200. Retrieved from: https://journal.unnes.ac.id/nju/index.php/JIPK $\angle$ article/view/15735. [Indonesian]

Asma, R., Asrial., Maison. (2020). Development of Interactive Electronic Student Worksheets on 
Electromagnetic Induction Based on Scientific Approaches. Jurnal Penelitian Pendidikan IPA (JPPIPA), 6(2), 136-143. $\quad$ DOI: 10.29303/jppipa.v6i2.387

Cahyadi, R.A.H. (2019). Pengembangan Bahan Ajar Berbasis ADDIE Model. Halaqa: Islamic Education Journal, 3(1): 35-43. DOI: https://doi.org/10.21070/halaqa.v3i1.2124. [Indonesian]

Fitri, A. (2016). Meningkatkan Hasil Belajar Siswa Menggunakan Model Pembelajaran SiMaYang Materi Kelarutan dan Hasil Kelarutan (Ksp). Jurnal Inovasi Pendidikan Sains, 7(2): 109-120. Retrieved

from: https://ppjp.ulm.ac.id/journal/index.php/quan tum/article/view/3574. [Indonesian]

Gregory, R.J. (2007). Psychological Testing: History, Principles, and Applications. Boston: Pearson.

Helsy, I., Maryamah, Farida, I., \& Ramdhani, M.A. (2017). Volta-Based Cells Materials Chemical Multiple Representation to Improve Ability of Student Representation. Journal of Physics: Conference Series, 895, 012010. DOI: https:// doi.org/10.1088/17426596/895/1/012010

Himmah, F., \& Martini. (2017). Pengembangan Multimedia Interaktif Menggunakan ISpring Suite 8 pada Sub Materi Zat Aditif untuk Meningkatkan Hasil Belajar Siswa SMP Kelas VIII. E-Journal Unesa, 5(2): 73-82. Retrieved from: https://jurnalmahasiswa.unesa.ac.id/index.php Lpensa/article/view/18834. [Indonesia]

Hsin I., Yung, \& Fred Paas. (2015). Effects of ComputerBased Visual Representation on Mathematics Learning and Cognitive Load. Journal of Educational Technology \& Society, 18(4), 70-77. Retrieved from http://www.jstor.org/stable/jeductechsoci.18.4.70

Ibrahim, Gunawan, \& Kosim. (2020). Validitas Perangkat Pembelajaran Fisika Berbasis Model Discovery Learning dengan Pendekatan Konflik Kognitif. Jurnal Pijar MIPA, 15(3): 214-218. DOI: http://dx.doi.org/10.29303/jpm.v15i3.1878.

[Indonesian]

Kusumaningsih, W., Darhim, Herman, T., \& Turmudi. (2018). Improvement Algebraic Thinking Ability using Multiple Representation Strategy on Realistic Mathematics Education. Journal on Mathematics Education, 9(2): 281-290. DOI: https://doi.org/10.22342/jme.9.2.5404.281-290

Lestari, D., Fibonacci, A., \& Alawiyah, N. (2020). Efektivitas Model Pembelajaran SiMaYang Tipe II Berbasis Multipel Representasi Terhadap Penguasaan Konsep dan Attitudes Toward Chemistry pada Materi Larutan Penyangga. Jurnal Pendidikan Kimia FKIP Universitas Halu
Oleo, 5(2): 93-104. Retrieved from: http://ojs.uho.ac.id/index.php/ipkim/article/v iew/13629. [Indonesian]

Li, W. S.S., \& Arshad, M.Y. (2014). Application of Multiple Representation Levels in Redox Reactions among Tenth Grade Chemistry Teachers. Journal of Turkish Science Education, 11(3): 35-52. Retrieved from: https://core.ac.uk/download/pdf/42919294.pdf

Mutia, N.B., \& Prasetyo, Z. K. (2018). The Effectiveness of Students' Worksheet Based on Multiple Representations to Increase Creative Thinking Skills. Journal of Education and Learning (EduLearn), 12(4): 631-637. DOI: http://dx.doi.org/10.11591/edulearn.v12i4.8487.

Noor, A. Y., \& Kurniasih, D. (2019). Pengembangan Lembar Kerja Peserta Didik (LKPD) Berbasis Multipel Representasi pada Materi Hukum Dasar Kimia Kelas X IPA senior SMAN 1 Sungai Raya. Jurnal Ilmiah, 7(1): 39-46. DOI: http://dx.doi.org/10.29406/ar-r.v7i1.1380.

[Indonesian]

Nurpratami, H., Farida, I., \& Helsy, I. (2015). Pengembangan Bahan Ajar pada Materi Laju Reaksi Berorientasi Multipel Representasi Kimia. Prosiding Simposium Nasional Inovasi dan Pembelajaran Sains: 353-356, Bandung, 8-9 Juni $2015 . \quad$ Retrieved from: https://www.researchgate.net/publication/320 557404_Pengembangan_Bahan_Ajar_pada_Mater i_Laju_Reaksi_Berorientasi_Multipel_Representa si_Kimia. [Indonesian]

Pahriah \& Hendrawani. (2018). Pengembangan Bahan Ajar Laju Reaksi dengan Multipel Representasi Berbasis Inkuiri. Hydrogen: Jurnal Kependidikan Kimia, 6(1): 32-42. $\underline{10.33394 / \text { hjkk.v6i1.1598. [Indonesian] }}$

Prastowo, A. (2015). Panduan Kreatif Membuat Bahan Ajar Inovatif. Yogjakarta: DIVA Press. [Indonesia]

Putri, G.E., dan Festiyed. (2019). Analisis Karakteristik Peserta Didik dalam Pembelajaran Fisika untuk Pengembangan Buku Digital (e-book) Fisika SMA Berbasis Model Discovery Learning. Jurnal Penelitian Pembelajaran Fisika, 5(2): 139-146. Retrieved from: http://ejournal.unp.ac.id/index.php/ippf/articl e/view/107437. [Indonesian]

Putrizal, I., Sunyono, dan Evkar, T. (2015). LKS Materi Larutan Elektrolit dan Non Elektrolit Berbasis Multipel Representasi Menggunakan Model SiMaYang. Jurnal Pendidikan dan Pembelajaran Kimia, 4(1): 236-247. Retrieved from: http://jurnal.fkip.unila.ac.id/index.php/JPK/ar ticle/view/8713. [Indonesian] 
Retnawati, H. (2016). Analisis Kuantitatif Instrumen Penelitian. Yogyakarta: Parama Publishing.

Sari, R. P., dan Seprianto. (2018). Analisis Kemampuan Multipel Representasi Mahasiswa FKIP Kimia Universitas Samudra Semester II Pada Materi Asam Basa dan Titrasi Asam Basa. Jurnal Pendidikan Sains Indonesia, 6(1): 55-62. DOI: https://doi.org/10.24815/jpsi.v6i1.10745.

[Indonesian]

Situmorang, A.S. (2020). Microsoft Teams for Education Sebagai Media Pembelajaran Interaktif Meningkatkan Minat Belajar. SEPREN: Journal of Mathematics Education and Applied, 2(1): 30-35. Retrieved from: https://jurnal.uhn.ac.id/index.php/sepren/arti cle/view/351. [Indonesian]

Sumaryati, I., Rahayu, R., \& Utaminingsih, S. (2018). Peningkatan Kemampuan Pemahaman Konsep Matematika Melalui Model Guided Discovery Learning Berbantuan Permainan Kaki Bima. Jurnal Ilmiah Pendidikan Matematika, 1(1): 59-66. DOI:https://doi.org/10.24176/anargya.v1i1.228 4. [Indonesian]

Sundami, N., \& Azhar, M. (2019). Pengembangan Modul Kesetimbangan Kimia Berbasis Inkuiri Terstruktur dengan Menggunakan 3 Level Representasi Kimia untuk Siswa Kelas XI SMA. EduKimia, $1(1)$ : 11-20. DOI: https://doi.org/10.24036/ekj.v1i1.104018. [Indonesian]

Sunyono, Yuanita, L., \& Ibrahim, M. (2015). Supporting Students in Learning With Multiple Representation to Improve Student Mental Models on Atomic Structure Concept. Science Education International, 26(2): 104-125. Retrieved from:: https://eric.ed.gov/?id=EJ1064043.

Sunyono, S., \& Meristin, A. (2018). The Effect of Multiple Representation-Based Learning (MRL) to Increase Students' Understanding of Chemical Bonding Concepts. Jurnal Pendidikan IPA Indonesia, $\quad 7(4): \quad 399-406 . \quad$ DOI: https://doi.org/10.15294/jpii.v7i4.16219.

Supriadi, N. (2015). Mengembangkan Kemampuan Koneksi Matematis Melalui Buku Ajar Elektronik Interaktif (BAEI) yang Terintegrasi Nilai-Nilai Keislaman. Al-Jabar: Jurnal Pendidikan Matematika, 6(1): 63-73. Retrieved from: http://ejournal.radenintan.ac.id/index.php/aljabar/article/view/51. [Indonesian]

Susilaningsih, E., Drastisianti, A., Lastri, Kusuma, E., \& Alighiri, D. (2019). The Analysis of Concept Mastery using Redox Teaching Materials with Multiple Representation and Contextual Teaching Learning Approach. Jurnal Pendidikan
IPA Indonesia, 8(4): 475: 481. DOI: https://doi.org/10.15294/jpii.v8i4.18072

Sutamiati, K., Sunyono, \& Efkar, T. (2015). LKS Berbasis Multipel Representasi Menggunakan Model SiMaYang Pada Materi Larutan Asam Basa. Jurnal Pendidikan dan Pembelajaran Kimia, 4(1): 15$26 . \quad$ Retrieved from: http://jurnal.fkip.unila.ac.id/index.php/JPK/ar ticle/view/8784. [Indonesian]

Wiyarsi, A., Fachriyah, A.R., Supriadi, D., \& Ibrahim, M. (2019). A Test of Analytical Thinking and Chemical Representation Ability on Rate Reaction Topic. Cakrawala Pendidikan, 3(8): 228242.

DOI: https://doi.org/10.21831/cp.v38i2.23062

Yuliana, D., Rudibyani, R. B., \& Evkar, T. (2018). Efektivitas LKS Berbasis Multipel Representasi Dalam Meningkatkan Penguasaan Konsep Materi Larutan Elektrolit-Non Elektrolit. Jurnal Pendidikan dan Pembelajaran Kimia, 7(2): 1-13. Retrieved from: http://jurnal.fkip.unila.ac.id/index.php/JPK/ar ticle/view/15123. [Indonesian] 